\title{
Adsorption of norovirus and ostreid herpesvirus type 1 to polymer membranes for the development of passive samplers
}

\author{
Hubert Francoise ${ }^{1,{ }^{*} \text {, Morga Benjamin }}{ }^{2}$, Renault $\operatorname{Tristan}^{3}$, Le Guyader Soizick ${ }^{1}$ \\ ${ }^{1}$ Ifremer, Laboratoire de Microbiologie, LSEM/SG2M, rue de l'île d'Yeu, BP 21105, 44311 NANTES \\ cedex 03, France \\ 2 Ifremer, Laboratoire de Génétique et Pathologie des Mollusques, SG2M Station de La Tremblade - \\ Ronce Les Bains - 17390 La Tremblade, France \\ ${ }^{3}$ Ifremer, Département Ressources Biologiques et Environnement; Nantes,France \\ * Corresponding author : Françoise Hubert, email address : francoise.vincent@ifremer.fr
}

\begin{abstract}
:
Aims

This study was performed to develop passive sampling methodology for the detection of two viruses in seawater in the area of shellfish production, The Norovirus (NoV), a human pathogen implicated in gastroenteritis outbreaks linked to oyster consumption and the ostreid herpesvirus type 1 (OsHV-1) a virus associated with mass mortalities of Pacific oysters.
\end{abstract}

Methods and Results

Commercially membranes were tested for their capacity to adsorb virus: Zetapor, gauze, nylon, low density polyethylene (LDPE) and Polyvinylidene difluoride (PVDF). Laboratory exposures of membranes to contaminated water samples (stool, sewage, seawater) were performed. Our data shown that the amount of NoV Gll genome per membrane measured with qRT-PCR increased with the time of exposure up to 24h, for all types of membranes except gauze. After 15 days of exposure, the amount of NoV Gll per membrane continued to increase only for nylon and LDPE. The amount of OsHV-1 per zetapor membrane was significantly increased as soon as $4 \mathrm{~h}$ of exposure, and after $24 \mathrm{~h}$ of exposure for all types of membranes. Exposure of membranes to serial dilutions of various samples revealed that the amount of NoV GIl and OsHV-1 per membrane is significantly higher in diluted samples. The detection of NoV and OsHV-1 respectively with zetapor and PVDF membranes were found to be more efficient than direct analysis of sewage and sea water Conclusions: All membranes immerged in contaminated samples adsorbed NoV GII and OsHV-1. The amount of both virus increased with the time of exposure. Zetapor and PVDF membranes seems to be more adapted to NoV Gll and OsHV-1 detection respectively. 
Significance and Impact of the study

Membranes tested will be used as passive samplers to improve the detection of virus in oyster production areas. Also, passive samplers could be a valuable tool for microbiome analysis with New Generation Sequencing.

\section{Introduction}

The presence of viral and bacterial pathogens in coastal waters can pose a threat to oyster production through negative health impacts on both oysters and oyster consumers. The connectivity of different water bodies in the marine environment favors the spread of infections between oyster 
populations, but also limits the application of potential protective measures conventionally used in terrestrial animal production. In the same way, while wastewater treatment can reduce pathogen contamination in some areas, this approach does not safeguard oysters against sporadic viral contamination caused by other non-point sources. In this context, warning systems that are based on pathogen monitoring of water bodies could play a role in limiting the impact of these pathogens on shellfish (Hellmer et al. 2014).

The direct detection of pathogens in water samples reflects only the pollution situation at the moment of sampling, however the concentration of pathogens can change rapidly, particularly in association with unexpected wastewater discharges. The same problem arises with the measurement of chemical contaminants in water and thus alternatives have been sought to improve the monitoring of chemical contaminants with passive sampling techniques (Vrana et al. 2014). Passive samplers are now widely used for monitoring organic and metallic contaminants in seawater and freshwater (Vrana et al. 2005; Mills et al. 2007) as they offer the ability to sample chemical contaminants over an extended period of time, avoiding overestimation or underestimation of contaminant concentrations. Moreover, this continuous sampling approach, gives a more representative concentration of real contamination than that provided by the analysis of grab samples (Vrana et al. 2005). This approach has also been used for marine biotoxin monitoring of shellfish (MacKenzie et al. 2004), and could be applied to the monitoring of viruses using appropriate devices.

Among the many human enteric viruses shed into the environment, norovirus (NoV) is currently the most frequent human pathogen detected in oysters and the most frequently implicated in gastroenteritis outbreaks linked to oyster consumption in Europe (EFSA 2012). NoV belongs to the Caliciviridae family, a group of non-enveloped, icosahedral viruses. The genus is divided into seven genogroups, three of them infect humans (GI, II and IV) (Atmar 2010). NoVs, which are excreted in large quantities in human feces, are very stable in the environment and can thus contaminate rivers and marine coastal waters that support oyster growth (Perez-Sautu et al.

This article is protected by copyright. All rights reserved. 
2012; Campos and Lees 2014). NoV contaminated oysters have been detected worldwide following the malfunction of wastewater treatment plants during heavy rainfall or extreme weather events and subsequent contamination of marine waters (Maalouf et al. 2010; Grodzki et al. 2012; Pu et al. 2016). After contamination, NoV may persist for up to two months in shellfish tissues and depuration is not efficient in reducing NoV levels(Richards et al. 2010; Drouaz et al. 2015).

Other types of viruses may also be present in coastal waters and bivalve pathogens such as ostreid herpesvirus type 1 (OsHV-1), which is associated with mass mortality events of Pacific oysters, represents a major threat for oyster production (Segarra et al. 2010; Garcia et al. 2011). Ostreid herpes virus 1 (OsHV-1) is part of the family of Malacoherpesviridae and Herpesviridae (Davison et al., 2005). In 2005, its genome was published (Davison et al., 2005). It is a double-stranded DNA enveloped virus with a diameter of about $120 \mathrm{~nm}$. Its genome size is 207,439 bp (Davison et al., 2005). The icosahedral capsid consists of 16 triangles, which confirms that it is indeed a herpesvirus, as this mesh-shaped geometric pattern is observed only in the members of this family. A virulent variant called $\mu$ Var has been recently reported in Europe as the main causative agent of mass mortality events affecting C. gigas. (Segarra et al. 2010; Martenot et al. 2011; Lynch et al. 2012; Peeler et al. 2012; Renault et al. 2012; Roque et al. 2012; Domeneghetti et al. 2014). These events illustrate the vulnerability of the oyster farming sector, which faces both infectious diseases and the contamination of growing waters by pathogens more generally.

To our knowledge, gauze is the only type of device used as passive sampler for the detection of viruses in sewers more than 60 years ago (Moore et al. 1952); despite it being considered as a promising tool, grab sampling of water is preferred (Ikner et al. 2012). However, other types of membranes may be more efficient in capturing viruses than gauze.

In order to select a membrane that can be used as a passive sampler, we determined whether two viruses, NoV and OsHV-1, non-enveloped and enveloped viruses respectively, could be passively adsorbed onto various commercially available membranes with different compositions and different physical characteristics. As part of the study, the stability of viral adsorption onto the This article is protected by copyright. All rights reserved. 
membranes was investigated. The kinetics of adsorption was determined for each virus type and the detection limit of the membranes was quantified to evaluate the membrane performance and develop the sampling protocol.

\section{Materials and Methods}

\section{Membranes}

Zetapor filter $(0.45 \mu \mathrm{m})$, an electropositive, charge-modified diatomaceous earth/cellulose filter, was purchased from 3M (Cergy-Pontoise, France). Low density polyethylene (LDPE) was purchased from Manutan (France). Nylon nets (100 $\mu \mathrm{m})$ were purchased from Mougel (France), and PVDF Immobilon $(0.45 \mu \mathrm{m})$ from Millipore (France). Gauze pads were sterile surgical gauze.

\section{Viruses}

For NoV, three titrated samples were used, (i) a stool sample positive for NoV GII.6 was used as a $10 \%$ suspension for the first experiments, (ii) outlet waters positive for NoV GII were collected from four waste water treatment plants and aliquots were kept frozen at $-20^{\circ} \mathrm{C}$ for all experiments, and (iii) natural seawater was contaminated with the NoV GII.6 stool sample to achieve a final titer of $10^{6}$ RNAc/L. All samples were kept frozen at $-20^{\circ} \mathrm{C}$ before use.

For OsHV-1, 20 oysters were injected with a viral suspension as previously reported (Schikorski et al. 2011a; Schikorski et al. 2011b) and were maintained for 24 hours in a $5 \mathrm{~L}$ aquarium to allow the virus to replicate. Oysters were then removed from the aquarium and the contaminated seawater was used for the experiments.

\section{Exposure of the membranes to contaminated water samples}

Membranes of LDPE, nylon, zetapor, gauze and PVDF were submerged in a beaker containing either stool suspension, sewage or contaminated seawater, and kept at room temperature $\left(20 \pm 2^{\circ} \mathrm{C}\right)$ with continuous mixing. The volume of water or stool suspension in the beaker were $500 \mathrm{~mL}$ and $5 \mathrm{~L}$ for

This article is protected by copyright. All rights reserved. 
NoV and OsHV-1 respectively. The membrane surfaces were $4 \mathrm{~cm}^{2}$ for experiments with stool suspension and $17 \mathrm{~cm}^{2}$ for experiments with sewage and seawater. The duration of exposure varied from $1 \mathrm{~h}$ to 15 days. At the end of the exposure period, the membranes were rinsed in sterile water for $30 \mathrm{sec}$ to eliminate non-adsorbed particles and viral nucleic acids (NAs). Control membranes consisted of membranes exposed either to tap water or to seawater negative for NoV and OsHV-1. Three independent experiments were carried out for each condition tested. All experiments were replicate at least three times, and samples were analyzed two times.

\section{Nucleic acid extractions}

For NoVs, nucleic acids (NAs) were extracted directly from the entire membrane using the Nuclisens extraction kit (bioMérieux, Lyon France). NA was eluted from the paramagnetic silica into $100 \mu$ of elution buffer (bioMérieux) and immediately analyzed or kept frozen at $-20^{\circ} \mathrm{C}$. RNA was extracted from $1 \mathrm{ml}$ sub-samples of stool suspension, raw sewage and seawater using the same kit. For OsHV1, total DNA was extracted directly from the membrane using the QiAamp tissue mini kit $^{\circledR}$ (QIAgen) according to the manufacturer's protocol. Elution was performed in $50 \mu \mathrm{L}$ of the elution buffer provided with the kit.

\section{NoV detection and quantification}

NoV RNA extracts were screened by real-time RT-PCR (rRT-PCR) using the previously published primers and probe for NoV GII (Le Guyader et al. 2009). rRT-PCR was performed on a MX3000 (Stratagene, Massy, France) using the Ultrasens-one-step Quantitative RT-PCR System (Invitrogen). All samples were analyzed in duplicate using $5 \mu \mathrm{l}$ of undiluted or tenfold diluted RNA extracts. A negative amplification control (water) was included in each amplification series. The cycle threshold

$\left(C_{T}\right)$ was defined as the cycle at which a significant increase in fluorescence occurred. The number of RNA copies present in positive samples was estimated using a standard curve based on an in vitro

This article is protected by copyright. All rights reserved. 
transcription plasmid containing nucleotides 4191 to 5863 of the Houston virus (Genbank EU310927) (Le Guyader et al. 2009). To be included in the quantitative analysis, all wells had to yield a $C_{T}$ value less than 39. The number of viral genomic copies was then determined based on the NA volume analyzed ( $5 \mu$ l of a $100 \mu \mathrm{l}$ NA extract). Inhibitor removal was checked by comparing $C_{T}$ values of pure and 10 -fold diluted NA extracts, and considering the standard curve slope. Samples presenting a $\Delta \mathrm{C}_{\mathrm{T}}$ of $<1$ were quantified using mean $\mathrm{Ct}$ values. For samples presenting a $\Delta \mathrm{C}_{\mathrm{T}}>1$, the $\mathrm{Ct}$ value used for quantification was the value obtained for the 10 -fold diluted sample and then corrected using the slope of the standard curve.

\section{OsHV-1 DNA detection and quantification}

OsHV-1 DNA detection and quantification were carried out using real-time PCR (rPCR) as previously described (Martenot et al. 2013). The target was the B region of the OsHV-1 genome, which encodes a putative apoptosis inhibitor (Arzul et al. 2001). Amplifcation was performed on a MX3000 (Stratagene, Massy, France) using the Brillant III Ultra-Fast PCR Master Mix (Agilent). All samples of undiluted viral DNA extracts were analysed in duplicate. A negative amplification control (water) was included in each amplification series. The virus quantitation was carried out by comparison with a standard curve constructed using five OsHV-1 DNA dilutions ranging from 30 to $10^{6}$ viral genome copies $/ \mu \mathrm{L}$.

\section{Calculation of the adsorption rate}

The adsorption rate was calculated to compare the adsorption capacity of each membrane. The formula used was:

Adsorption rate $(\%)=(\mathrm{cp} \mathrm{M} / \mathrm{cp} \mathrm{S}) * 100$

where $\mathrm{cp} \mathrm{M}$ = copies of viral genome measured in the membrane extract

This article is protected by copyright. All rights reserved. 
and $\mathrm{cp} \mathrm{S}=$ copies of viral genome measured in the sample $(1 \mathrm{ml}$ of stool suspension or sewage or seawater) $\mathrm{X}$ volume of water in the beaker

\section{Statistical analysis:}

To determine whether the amount of virus adsorbed on membrane vary according to the type of membrane, we performed a non-parametric Kruskal-Wallis test. In the other case, the Student t test was performed to evaluate possible significant differences between mean values of a same membrane. Three levels were considered significant: $p<0.05\left({ }^{*}\right), p<0.01\left({ }^{* *}\right)$ and $p<0.001\left({ }^{* * *}\right)$. All statistical analyses were performed with the prism 7 software.

\section{Results}

\section{Stability of virus adsorption onto membranes}

The stability of the virus adsorption onto zetapor, nylon, LDPE, PVDF and gauze was tested (Table 1). To evaluate stability, membranes were exposed for $1 \mathrm{~h}$ to either sewage (NoV Gll contamination) or seawater (OsHV-1 contamination) and were then immerged in MilliQ water for 30 min. For both NoV GII and OsHV-1, no significant difference were observed between the amount of genome copies on rinsed membranes compared to non-rinsed membranes, suggesting that virus adsorption was stable.

\section{Kinetics of viral adsorption to membranes and adsorption rates}

Membranes were exposed for $1 \mathrm{~h}, 4 \mathrm{~h}, 24 \mathrm{~h}$ and 15 days to sewage contaminated with NoV GII or for $1 \mathrm{~h}, 4 \mathrm{~h}$ and $24 \mathrm{~h}$ to seawater contaminated with OsHV-1. For OshV-1, the amount of genome copies on zetapor membrane increased as soon as $4 \mathrm{~h}$ of exposure when compared with $1 \mathrm{~h}$ of exposure

This article is protected by copyright. All rights reserved. 
$(p<0.001)$. The amount of NoV GII and OsHV-1 on membranes were significantly higher after $24 \mathrm{~h}$ of exposure compare with $1 \mathrm{~h}$ of exposure $(p<0.05)$, for all types of membrane except gauze and LDPE for NoV GII (Table 2). After two weeks of exposure, the amount of RNAc of NoV GII was higher on zetapor, nylon and LDPE membranes compare with $1 \mathrm{~h}$. For NoV GIl, Zetapor membrane had the highest rate of adsorption up to $24 \mathrm{~h}$ of exposure while LDPE always had the lowest rate regardless of the time of exposure. After 15 days of exposure, the nylon and zetapor membranes displayed the highest adsorption rates for NoV GII with $2 \%$ and $1.7 \%$, respectively. For OsHV-1, gauze and PVDF displayed the highest adsorption rates with $0.23 \%$ and $0.17 \%$, respectively (Table 2 ). For the same exposure time, no significant difference was observed between the amounts of virus adsorbed on the four types of membranes..

\section{Serial dilutions of contaminated samples and adsorption rate}

The lowest amount of virus that could be detected by the membranes was determined by exposure to serial dilutions of contaminated samples.

For membranes exposed for $1 \mathrm{~h}$ to diluted stool suspensions, NoV GIl genome copies decreased significantly on the gauze, nylon and zetapor membranes between the $10^{-2}$ and $10^{-5}$ dilutions $(p<0.5)$, and also declined significantly between the $10^{-1}$ and $10^{-5}$ dilutions for LDPE $(p<0.5)$ (Table 3 ). Adsorption rates were higher for diluted samples, with the highest values of $44 \%, 10.9 \%, 15 \%$ and $18 \%$ recorded for gauze, LDPE, nylon and Zetapor respectively. Low concentrations of NoV genome copies (< LOD) were detected on all membrane types immersed in the $10^{-5}$ diluted stool suspension, except nylon. For the same dilution, the amount of NoV GII did not vary significantly between the four types of membranes.

For sewage samples, the experiments were performed only with zetapor membrane (Table 4). The number of NoV GIl genome copies per membrane decreased significantly with the dilution of

This article is protected by copyright. All rights reserved. 
sewage samples and was detected up to the $10^{-4}$ dilution $(p<0.5)$. In contrast, NoV GII could only be directly detected in undiluted, $10^{-1}$ and $10^{-2}$ dilutions of sewage. The amount of of NoV GII per membrane is significantly higher than in sewage for dilution -1 and $-2(p<0.01)$.

For seawater analysis, NoV GII was detected only in the undiluted and $10^{-1}$ dilutions, both with membranes and by direct analysis of the water (Table 4). Similar amounts of genome copies were detected on membranes exposed to undiluted and 10-fold dilutions, which demonstrates that adsorption is enhanced in samples that are diluted 10 -fold: adsorption was 39 times higher for sewage samples and 9 times higher for seawater (Table 4). Additionally, for 10 -fold diluted sample, the amount of genome copies per membranes is significantly higher than in sea water $(p<0.5)$

For OsHV-1, only the LDPE and PVDF membranes were exposed to serial dilutions of seawater samples (Table 5). The amount of OsHV-1 DNA measured in LDPE and PVDF extracts decreased significantly with dilution ( $p<0.5$ to $p<0.001$ ). The amount detected in PVDF membrane extracts was significantly higher than in the corresponding $200 \mu \mathrm{L}$ seawater sample $(p<0.001)$. Moreover, the amount of OsHV-1 DNA measured in the PVDF extracts was significantly higher than that of LDPE extracts $(p<0.01)$.

\section{Discussion}

This study is the first to assess the detection of NoV GII and OsHV-1 using various types of membranes immersed in contaminated water samples. Our data demonstrates the potential of these membranes as passive samplers for future field applications. The real time PCR methods used in this study are identical to those currently used for the direct detection of virus in oyster tissues and water (Le Guyader et al. 2009; Martenot et al. 2013). Two of the membranes (Zetapor and nylon) evaluated are currently used for water filtration: nylon is used in the pre-filtration of water samples and Zetapor filter is an electropositive filter, recommended for the recovery of NoV or hepatitis A virus in the ISO/Cen method (15216-1 2013). PVDF, a membrane currently used in

This article is protected by copyright. All rights reserved. 
protein analysis, was selected because of its capacity to interact with viral proteins. Low Density Polyethylene membranes (LDPE), was included as a passive sampler of biofilm, as many viruses are associated with biofilm (Skraber et al. 2009).

The adsorption of both viruses on membranes may be influenced by several parameters, however the factors influencing OsHV-1 adsorption on inert surfaces are currently unknown. Among these parameters are physical characteristics of the virus (i.e. isoelectric point, $\mathrm{pH}$, particle size), membrane properties (i.e. electric charge, hydrophobicity) and aqueous solution characteristics ( $\mathrm{pH}$, ionic strength) (Gerba 1984; da Silva et al. 2011). It is known that NoV particles aggregate at pH around the isoelectric point (around $\mathrm{pH} 4$ ) at room temperature, while individual particles are observed at pH's above their isoelectric point (Samandoulgou et al. 2015a). Therefore, for sewage or seawater with a pH of about 6 to 7, NoVs are negatively charged which explains their adsorption on the electropositive Zetapor membrane. Concerning the LDPE membrane, its hydrophobic nature may favor interactions with viruses. Hydrophobic binding is thought to significantly contribute to the strength of adhesive interactions between proteins and surfaces, which may explain NoV and OsHV1 adsorption on LDPE (Sallberg et al. 1995; Samandoulgou et al. 2015b). Although Zetapor has been used previously in studies focusing on vertebrate herpesviruses, there is no data on the adsorption of these viruses onto other membrane types, such as those used in the present study. Zetapor membrane was previously used to study the survival rate of suid herpesvirus 1 , the Aujeszky's disease virus, in composted sewage sludge (Paluszak et al. 2012).

The increase in the duration of immersion of the membranes allowed a higher recovery of viral NAs which highlights the potential of these membranes to provide time-integrated sampling of virus particles. For NoV, this was observed for short (24h) and long exposure (2 weeks). The increase of virus after a 2 week exposure could be explained by the formation of a biofilm. Indeed, it is well known that bacteria can establish a biofilm on LDPE and nylon (Fechner et al. 2010), and that NoV can attach more readily to some bacteria, particularly those that capture NoV due to the presence of

This article is protected by copyright. All rights reserved. 
histo-blood group antigens on their surface (Miura et al. 2013). A second hypothesis, which has been suggested previously for NoV interactions with bottled water and clay (Lipson and Stotzky 1985; Butot et al. 2007), is that bacterial components may reduce the electrostatic repulsion forces between the viruses and the LDPE, thereby permitting the viruses to approach the LDPE surface and facilitate adsorption. For gauze pads, the adsorption rate of NoV did not increase after one hour of immersion as previously observed (Fattal and Katzenelson 1976). For OsHV-1, the increase adsorption observed up to $24 \mathrm{~h}$ with Zetapor and nylon suggests that they are more appropriate for the OsHV-1 detection.

Surprisingly, the adsorption rates of NoV GIl on membranes were increased in all diluted samples and all sample types evaluated (stool, sewage, seawater). As previously reported the presence of high concentrations of dissolved organic matter reverses the charge of the membrane surface, and therefore NoV GII was not completely retained on zetapor filter membranes (Da Silva et al. 2008). For OsHV-1, the adsorption rate did not increase in diluted samples, therefore it is suggested that organic material may not readily influence the adsorption of these viruses onto membranes.

In conclusion, the data presented in this paper clearly show the promise of a variety of membranes as passive samplers for NoV and OsHV-1. For short exposure, zetapor seems to be more adapted to norovirus, while for long exposure, nylon and zetapor display similar adsorption rate; for OsHV-1, PVDF is more adapted. Several types of field applications using passive sampling are proposed: (1) short exposure to samplers will allow qualitative detection; and (2) long exposure to samplers will give an integrated concentration per membrane over a period of time. Following further verification of these membranes to capture other pathogens, they may be a valuable tool for microbiome investigations with New Generation Sequencing.

This article is protected by copyright. All rights reserved. 


\section{Acknowledgment}

This research project was supported by the Region Pays de la Loire (France), the SMIDAP (contract number 2014-04602) and the EU funded project VIVALDI (H2020 $\left.n^{\circ} 678589\right)$. We are grateful to Catherine McLeod (Seafood Safety Assessment) for a critical review of the manuscript.

\section{Conflict of interest:}

All the authors have no conflict of interest.

\section{References}

15216-1, X.C.I.T. (2013) Microbiology of food and animal feed - Horizontal method for determination of hepatitis A virus and norovirus in food using real-time RT PCR - Part 1: method of quantification Arzul, I., Nicolas, J.L., Davison, A.J. and Renault, T. (2001) French scallops: A new host for ostreid herpesvirus-1. Virology 290, 342-349.

Atmar, R.L. (2010) Noroviruses: state of the art. Food Environ Virol 2, 117-126.

Butot, S., Putallaz, T., Croquet, C., Lamothe, G., Meyer, R., Joosten, H. and Sanchez, G. (2007) Attachment of enteric viruses to bottles. Appl Environ Microbiol 73, 5104-5110.

Campos, C.J.A. and Lees, D.N. (2014) Environmental transmission of human Noroviruses in shellfish waters. Appl Environ Microbiol 80, 3552-3561.

da Silva, A.K., Kavanagh, O.V., Estes, M.K. and Elimelech, M. (2011) Adsorption and Aggregation Properties of Norovirus GI and GII Virus-like Particles Demonstrate Differing Responses to Solution Chemistry. Environ Sci Technol 45, 520-526.

Da Silva, A.K., Le Guyader, F.S., Le Saux, J.-C., Pommepuy, M., Montgomery, M.A. and Elimelech, M. (2008) Norovirus Removal and Particle Association in a Waste Stabilization Pond. Environ Sci Technol 42, 9151-9157.

Domeneghetti, S., Varotto, L., Civettini, M., Rosani, U., Stauder, M., Pretto, T., Pezzati, E., Arcangeli, G., Turolla, E., Pallavicini, A. and Venier, P. (2014) Mortality occurrence and pathogen detection in Crassostrea gigas and Mytilus galloprovincialis close-growing in shallow waters (Goro lagoon, Italy). Fish Shellfish Immunol 41, 37-44.

Drouaz, N., Schaeffer, J., Farkas, T., Le Pendu, J. and Le Guyader, F.S. (2015) Tulane virus as a potential surrogate to mimic Norovirus behavior in oysters. Appl EnvironMicrobiol 81, 5249-5256.

EFSA (2012) Scientific Opinion on Norovirus (NoV) in oysters: methods, limits and control options. EFSA J 10, 39.

Fattal, B. and Katzenelson, E. (1976) Evaluation of gauze pad method to recover viruses from water Water Res10, 1135-1140.

Fechner, L.C., Vincent-Hubert, F., Gaubert, P., Bouchez, T., Gourlay-France, C. and Tusseau-Vuillemin, M.-H. (2010) Combined eukaryotic and bacterial community fingerprinting of natural freshwater biofilms using automated ribosomal intergenic spacer analysis. Fems Microbiol Ecol74, 542-553.

Garcia, C., Thebault, A., Degremont, L., Arzul, I., Miossec, L., Robert, M., Chollet, B., Francois, C., Joly, J.-P., Ferrand, S., Kerdudou, N. and Renault, T. (2011) Ostreid herpesvirus 1 detection and relationship with Crassostrea gigas spat mortality in France between 1998 and 2006. Vet Res 42, 7284.

Gerba, C.P. (1984) Applied and theoretical aspects of virus adsorption to surfaces Ad Appl Microbiol 30, 133-168.

Grodzki, M., Ollivier, J., Le Saux, J.-C., Piquet, J.-C., Noyer, M. and Le Guyader, F.S. (2012) Impact of

This article is protected by copyright. All rights reserved. 
Xynthia tempest on viral contamination of shellfish. Appl EnvironMicrobiol 78, 3508-3511.

Hellmer, M., Paxeus, N., Magnius, L., Enache, L., Arnholm, B., Johansson, A., Bergstrom, T. and Norder, H. (2014) Detection of Pathogenic Viruses in Sewage Provided Early Warnings of Hepatitis A Virus and Norovirus Outbreaks. Appl Environ Microbiol 80, 6771-6781.

Ikner, L.A., Gerba, C.P. and Bright, K.R. (2012) Concentration and Recovery of Viruses from Water: A Comprehensive Review. Food Environ Virol 4, 41-67.

Le Guyader, F.S., Parnaudeau, S., Schaeffer, J., Bosch, A., Loisy, F., Pommepuy, M. and Atmar, R.L. (2009) Detection and Quantification of Noroviruses in Shellfish. Appl Environ Microbio/75, 618-624.

Lipson, S.M. and Stotzky, G. (1985) Effect of bacteria on the inactivation and adsorption on clayminerals of reovirus Can J Microbiol 31, 730-735.

Lynch, S.A., Carlsson, J., Reilly, A.O., Cotter, E. and Culloty, S.C. (2012) A previously undescribed ostreid herpes virus 1 (OsHV-1) genotype detected in the pacific oyster, Crassostrea gigas, in Ireland. Parasitology 139, 1526-1532.

Maalouf, H., Pommepuy, M. and Le Guyader, F.S. (2010) Environmental conditions leading to shellfish contamination and related outbreaks. Food Environ Virol 2, 136-145.

MacKenzie, L., Beuzenberg, V., Holland, P., McNabb, P. and Selwood, A. (2004) Solid phase adsorption toxin tracking (SPATT): a new monitoring tool that simulates the biotoxin contamination of filter feeding bivalves. Toxicon 44, 901-918.

Martenot, Oden, E., Travaille, E., Malas, J.P. and Houssin, M. (2011) Detection of different variants of Ostreid Herpesvirus 1 in the Pacific oyster, Crassostrea gigas between 2008 and 2010. Virus Res160, 25-31.

Martenot, Travaille, E., Lethuillier, O., Lelong, C. and Houssin, M. (2013) Genome exploration of six variants of the Ostreid Herpesvirus 1 and characterization of large deletion in OsHV-1 mu Var specimens. Virus Res 178, 462-470.

Mills, G.A., Vrana, B., Allan, I., Alvarez, D.A., Huckins, J.N. and Greenwood, R. (2007) Trends in monitoring pharmaceuticals and personal-care products in the aquatic environment by use of passive sampling devices. Anal Bioanal Chem 387, 1153-1157.

Miura, T., Sano, D., Suenaga, A., Yoshimura, T., Fuzawa, M., Nakagomi, T., Nakagomi, O. and Okabe, S. (2013) Histo-Blood Group Antigen-Like Substances of Human Enteric Bacteria as Specific Adsorbents for Human Noroviruses. J Virol 87, 9441-9451.

Moore, B., Perry, E.L. and Chard, S.T. (1952) A survey by the sewage swab method of latent enteric infection in an urban area. J Hyg 50, 137-156.

Paluszak, Z., Lipowski, A. and Ligocka, A. (2012) Survival rate of Suid Herpesvirus (SuHV-1, Aujeszky's disease virus, ADV) in composted sewage sludge. Pol J Vet Sci 15, 51-54.

Peeler, E.J., Reese, R.A., Cheslett, D.L., Geoghegan, F., Power, A. and Thrush, M.A. (2012) Investigation of mortality in Pacific oysters associated with Ostreid herpesvirus-1 mu Var in the Republic of Ireland in 2009. Prev Vet Med 105, 136-143.

Perez-Sautu, U., Sano, D., Guix, S., Kasimir, G., Pinto, R.M. and Bosch, A. (2012) Human norovirus occurrence and diversity in the Llobregat river catchment, Spain. Environ Microbiol 14, 494-502.

Pu, J., Kazama, S., Miura, T., Dhyan Azraini, N., Konta, Y., Ito, H., Ueki, Y., Eka Cahyaningrum, E., Omura, T. and Watanabe, T. (2016) Pyrosequencing Analysis of Norovirus Genogroup II Distribution in Sewage and Oysters: First Detection of GII.17 Kawasaki 2014 in Oysters. Food Environ Virol in press.

Renault, T., Moreau, P., Faury, N., Pepin, J.F., Segarra, A. and Webb, S. (2012) Analysis of Clinical Ostreid Herpesvirus 1 (Malacoherpesviridae) Specimens by Sequencing Amplified Fragments from Three Virus Genome Areas. J Virol 86, 5942-5947.

Richards, G.P., McLeod, C. and Le Guyader, F.S. (2010) Processing strategies to inactivate enteric viruses in shellfish. Food Environ Virol 2, 183-193.

Roque, A., Carrasco, N., Andree, K.B., Lacuesta, B., Elandaloussi, L., Gairin, I., Rodgers, C.J. and Furones, M.D. (2012) First report of OsHV-1 microvar in Pacific oyster (Crassostrea gigas) cultured in Spain. Aquaculture 324, 303-306.

This article is protected by copyright. All rights reserved. 
Sallberg, M., Blixt, M., Zhang, Z.X. and Ekstrand, J. (1995) Passive adsorption of immunologically active and inactive synthetic peptides to polystryrene is influenced by the proportion of non polar residues in the peptide Immunol Lett 46, 25-30.

Samandoulgou, I., Fliss, I. and Jean, J. (2015a) Zeta Potential and Aggregation of Virus-Like Particle of Human Norovirus and Feline Calicivirus Under Different Physicochemical Conditions. Food Environ Viro/7, 249-260.

Samandoulgou, I., Hammami, R., Morales Rayas, R., Fliss, I. and Jean, J. (2015b) Stability of secondary and tertiary structures of virus-like particles representing Noroviruses: Effects of $\mathrm{pH}$, ionic strength, and temperature and implications for adhesion to surfaces. Appl environ microbiol 81, 7680-7686.

Schikorski, D., Faury, N., Pepin, J.F., Saulnier, D., Tourbiez, D. and Renault, T. (2011a) Experimental ostreid herpesvirus 1 infection of the Pacific oyster Crassostrea gigas: Kinetics of virus DNA detection by q-PCR in seawater and in oyster samples. Virus Res 155, 28-34.

Schikorski, D., Renault, T., Saulnier, D., Faury, N., Moreau, P. and Pepin, J.F. (2011b) Experimental infection of Pacific oyster Crassostrea gigas spat by ostreid herpesvirus 1: demonstration of oyster spat susceptibility. Vet Res $\mathbf{4 2 .}$

Segarra, A., Pepin, J.F., Arzul, I., Morga, B., Faury, N. and Renault, T. (2010) Detection and description of a particular Ostreid herpesvirus 1 genotype associated with massive mortality outbreaks of Pacific oysters, Crassostrea gigas, in France in 2008. Virus Research 153, 92-99.

Skraber, S., Ogorzaly, L., Helmi, K., Maul, A., Hoffmann, L., Cauchie, H.-M. and Gantzer, C. (2009) Occurrence and persistence of enteroviruses, noroviruses and F-specific RNA phages in natural wastewater biofilms. Water Res 43, 4780-4789.

Vrana, B., Klucarova, V., Benicka, E., Abou-Mrad, N., Amdany, R., Horakova, S., Draxler, A., Humer, F. and Gans, O. (2014) Passive sampling: An effective method for monitoring seasonal and spatial variability of dissolved hydrophobic organic contaminants and metals in the Danube river. Environ Pollut 184, 101-112.

Vrana, B., Mills, G.A., Allan, I.J., Dominiak, E., Svensson, K., Knutsson, J., Morrison, G. and Greenwood, R. (2005) Passive sampling techniques for monitoring pollutants in water. Trends Analyt Chem24, 845-868.

Table 1: Stability of NoV GII and OsHV-1 on the various types of membranes

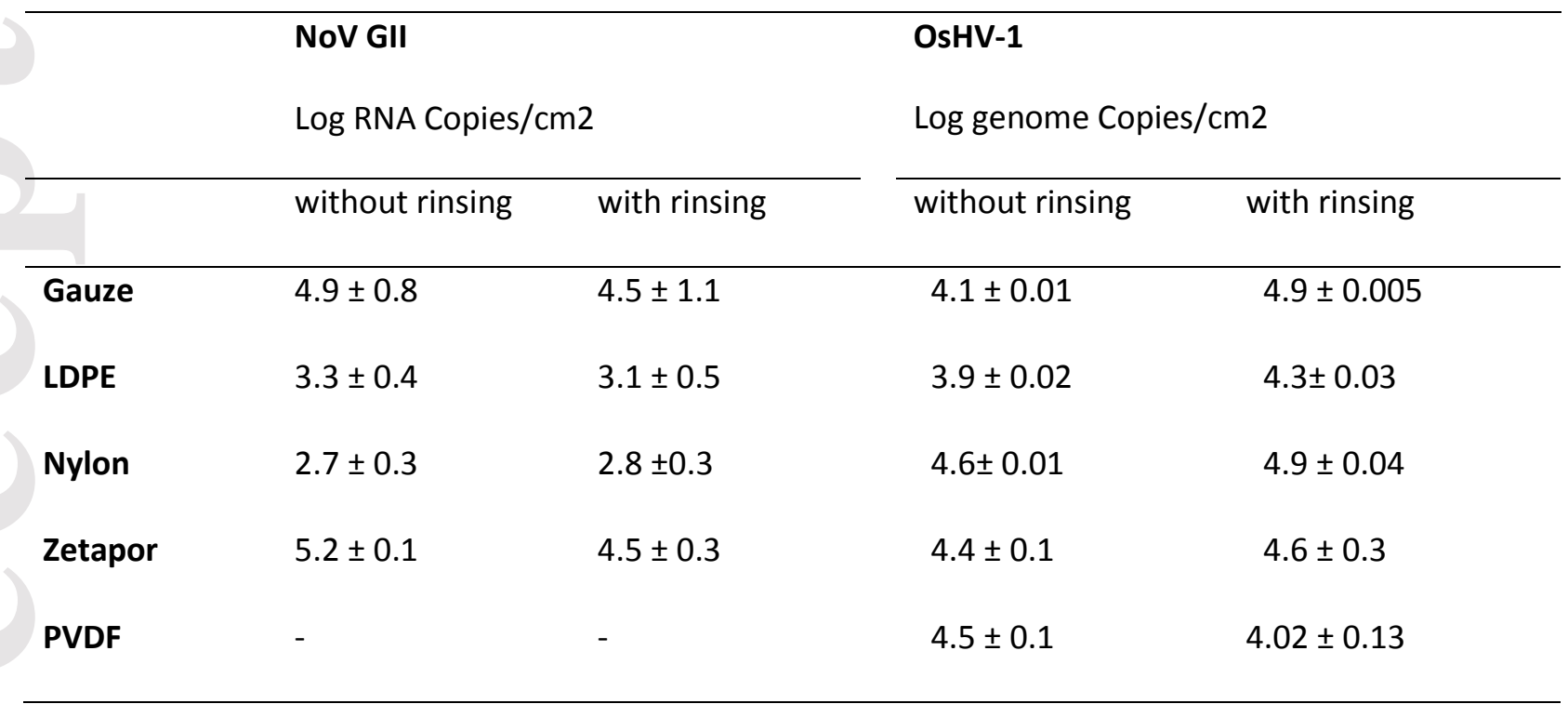

This article is protected by copyright. All rights reserved. 
Table 2: Kinetics of adsorption of NoV GII and OsHV-1 on various types of membranes exposed to sewage

\begin{tabular}{|c|c|c|c|c|c|c|c|c|c|c|c|}
\hline & & \multicolumn{2}{|l|}{ zetapor } & \multicolumn{2}{|l|}{ Nylon } & \multicolumn{2}{|l|}{ LDPE } & \multicolumn{2}{|l|}{ gauze } & \multicolumn{2}{|l|}{ PVDF } \\
\hline & & $\begin{array}{l}\text { Log RNA or } \\
\text { gen.copies/ } \\
\mathrm{cm}^{2}\end{array}$ & $\begin{array}{l}\text { adsorption } \\
\text { rate } \%\end{array}$ & $\begin{array}{l}\text { Log RNA or } \\
\text { gen.copies/ } \\
\mathrm{cm}^{2}\end{array}$ & $\begin{array}{l}\text { adsorption } \\
\text { rate } \%\end{array}$ & $\begin{array}{l}\text { Log RNA or } \\
\text { gen.copies/ } \\
\mathrm{cm}^{2}\end{array}$ & $\begin{array}{l}\text { adsorption } \\
\text { rate } \%\end{array}$ & $\begin{array}{l}\text { Log RNA or } \\
\text { gen.copies/ } \\
\mathrm{cm}^{2}\end{array}$ & $\begin{array}{l}\text { adsorption } \\
\text { rate } \%\end{array}$ & $\begin{array}{l}\text { Log RNA or } \\
\text { gen.copies/ } \\
\mathrm{cm}^{2}\end{array}$ & $\begin{array}{l}\text { adsorption } \\
\text { rate } \%\end{array}$ \\
\hline \multirow[t]{2}{*}{$1 \mathrm{~h}$} & NoV GII & $2.66 \pm 0.1$ & 0.26 & $1.75 \pm 0.9$ & 0.03 & $1.99 \pm 0.3$ & 0.01 & $3.1 \pm 0.06$ & 0.14 & - & - \\
\hline & OsHV-1 & $2.64 \pm 0.08$ & 0.013 & $3.36 \pm 0.15$ & 0.07 & $2.36 \pm 0.04$ & 0.006 & $3.54 \pm 0.19$ & 0.1 & $2.8 \pm 0.11$ & 0.02 \\
\hline \multirow[t]{2}{*}{$4 h$} & NoV GII & $2.85 \pm 0.2$ & 0.42 & $2.35 \pm 0.6$ & 0.1 & $2.35 \pm 0.9$ & 0.026 & $3.03 \pm 0.2$ & 0.12 & - & - \\
\hline & OsHV-1 & $3.19 \pm 0.08 * * *$ & 0.05 & $3.32 \pm 0.08$ & 0.061 & $2.58 \pm 0.17$ & 0.01 & $2.93 \pm 0.0$ & 0.24 & $3.05 \pm 0.32$ & 0.04 \\
\hline \multirow[t]{2}{*}{$24 \mathrm{~h}$} & NoV GII & $3.45 \pm 0.3 *$ & 1.66 & $2.62 \pm 0.01 * *$ & 0.24 & $2.81 \pm 0.9$ & 0.07 & $3.24 \pm 0.3$ & 0.2 & - & - \\
\hline & OsHV-1 & $3.30 \pm 0.04 * * *$ & 0.06 & $3.75 \pm 0.08 * *$ & 0.16 & $2.78 \pm 0.04^{* *}$ & 0.02 & $3.91 \pm 0.01 *$ & 0.23 & $3.30 \pm 0.1 * * *$ & 0.165 \\
\hline $\begin{array}{l}15 \\
\text { days }\end{array}$ & NoV GII & $3.49 \pm 0.2^{*}$ & 1.7 & $3.55 \pm 0.3^{*}$ & 2.04 & $3.34 \pm 0.8^{*}$ & 0.24 & $3.26 \pm 0.4$ & 0.2 & - & - \\
\hline
\end{tabular}

Log of genomic copies are reported as mean \pm standard deviation. ${ }^{*} \mathrm{P}<0.05 ; * * \mathrm{p}<0.01 ; * * * \mathrm{p}<0.001$

$\left({ }^{*}\right)$ for $4 \mathrm{~h}, 24 \mathrm{~h}, 15$ days compared with $1 \mathrm{~h}$.

This article is protected by copyright. All rights reserved. 
Table 3: NoV GII genome copies detected on membranes exposed to serial dilutions of stool suspension and associated adsorption rates

\begin{tabular}{|c|c|c|c|c|c|c|c|c|}
\hline \multirow{2}{*}{$\begin{array}{l}\text { Serial } \\
\text { dilutions } \\
\text { of stool } \\
\text { suspension }\end{array}$} & \multicolumn{2}{|l|}{ Gauze } & \multicolumn{2}{|l|}{ LDPE } & \multicolumn{2}{|l|}{ Nylon } & \multicolumn{2}{|l|}{ Zetapor } \\
\hline & $\begin{array}{l}\text { Log gen. } \\
\text { copies/cm2 }\end{array}$ & $\begin{array}{l}\text { adsorption } \\
\text { rate } \%\end{array}$ & $\begin{array}{l}\text { Log gen. } \\
\text { copies/cm2 }\end{array}$ & $\begin{array}{l}\text { adsorption } \\
\text { rate } \%\end{array}$ & $\begin{array}{l}\text { Log gen. } \\
\text { copies } / \mathrm{cm}^{2}\end{array}$ & $\begin{array}{l}\text { adsorption } \\
\text { rate } \%\end{array}$ & $\begin{array}{l}\text { Log gen. } \\
\text { copies } / \mathrm{cm}^{2}\end{array}$ & $\begin{array}{l}\text { adsorption } \\
\text { rate } \%\end{array}$ \\
\hline Pure & $5.1 \pm 0.3$ & 0.15 & $5.6 \pm 0.3$ & 0.5 & $5.53 \pm 0.6$ & 0.4 & $5.5 \pm 0.3$ & 0.4 \\
\hline $1 / 10$ & $5.5 \pm 0.2$ & 4.4 & $5.06 \pm 0.2$ & 1.39 & $5.47 \pm 0.3$ & 3.5 & $6.3 \pm 0.3$ & 24.22 \\
\hline $1 / 100$ & $5.1 \pm 0.4$ & 15.13 & $4.6 \pm 0.3$ & 4.8 & $5.4 \pm 0.7$ & 35.7 & $5.1 \pm 0.3$ & 15.5 \\
\hline $1 / 1000$ & $4 \pm 0.09$ & 12 & $3.7 \pm 0.5 *$ & 5.7 & $4.1 \pm 0.9 *$ & 15 & $4 \pm 0.2^{*}$ & 11.86 \\
\hline $1 / 10000$ & $3.5 \pm 0.03 *$ & 44.1 & $2.95 \pm 0.5^{*}$ & 10.9 & $2.8 \pm 0.7^{*}$ & 8.1 & $3.2 \pm 0.02 *$ & 18 \\
\hline $1 / 100000$ & $0.01 \pm 0.2 *$ & 0.08 & $0.33 \pm 0.2^{*}$ & 0.26 & $\mathrm{Nd}$ & $\mathrm{Nd}$ & $0.1 \pm 0.01 *$ & 0.15 \\
\hline
\end{tabular}

$\log _{10}$ of genomic copies are reported as mean \pm standard deviation. ${ }^{*} \mathrm{P}<0.05 ;\left(^{*}\right)$ for diluted compared with pure.

This article is protected by copyright. All rights reserved. 
Table 4: Amount of NoV GII measured on zetapor membranes exposed to serial dilutions of sewage or seawater and associated adsorption rates

\begin{tabular}{|c|c|c|c|c|c|c|}
\hline \multirow[t]{3}{*}{ Serial dilutions } & \multicolumn{3}{|l|}{ Sewage } & \multicolumn{3}{|l|}{ Seawater } \\
\hline & \multicolumn{2}{|l|}{ Zetapor } & \multirow{2}{*}{$\begin{array}{l}\text { water } \\
\text { Log genome copies/ml }\end{array}$} & \multicolumn{2}{|l|}{ Zetapor } & \multirow{2}{*}{$\begin{array}{l}\text { water } \\
\text { Log genome copies/ml }\end{array}$} \\
\hline & Log gen. copies $/ \mathrm{cm}^{2}$ & adsorption rate $\%$ & & $\begin{array}{ll}\text { Log } & \text { gen. } \\
\text { copies } / \mathrm{cm}^{2} & \end{array}$ & adsorption rate $\%$ & \\
\hline pure & $3.50 \pm 0.5$ & 0.9 & $3.63 \pm 0.3$ & $3.86 \pm 0.1 *+$ & 0.62 & $3.43 \pm 0.01$ \\
\hline $1 / 10$ & $3.27 \pm 0.6+\dagger$ & 3.56 & $2.25 \pm 0.2$ & $3.24 \pm 0.02 *+$ & 5.6 & $1.84 \pm 0.2 *$ \\
\hline $1 / 100$ & $2.35 \pm 0.3^{*}+\dagger$ & 0.74 & $1.53 \pm 0.2$ & nd & - & nd \\
\hline $1 / 1000$ & $1.64 \pm 0.3^{*}$ & - & nd & nd & - & nd \\
\hline $1 / 10000$ & $1.74 \pm 0.3 * *$ & - & nd & nd & - & nd \\
\hline
\end{tabular}

Log of genomic copies are reported as mean \pm standard deviation. * or $+\mathrm{P}<0.05 ; * *$ ort† $p<0.01$.

$(*)$ for diluted samples compared with pure; $(\dagger)$ for zetapore compared with water. Nd: not detected

This article is protected by copyright. All rights reserved. 
Table 5: Quantities of OsHV-1 measured on zetapor membranes exposed to serial dilutions of seawater and associated adsorption rates

\begin{tabular}{|c|c|c|c|c|c|}
\hline \multirow{2}{*}{$\begin{array}{l}\text { Serial } \\
\text { dilution of } \\
\text { sea water }\end{array}$} & \multicolumn{2}{|l|}{ LDPE } & \multicolumn{2}{|l|}{ PVDF } & Seawater \\
\hline & $\begin{array}{l}\text { Log gen. } \\
\text { copies } / \mathrm{cm}^{2}\end{array}$ & adsorption rate \% & $\begin{array}{l}\text { Log } \\
\text { copies } / \mathrm{cm}^{2}\end{array}$ & adsorption rate $\%$ & $\begin{array}{l}\text { Log genome } \\
\text { copies/ml }\end{array}$ \\
\hline $1 / 10$ & $1.98 \pm 0.04$ & 0.01 & $2.32 \pm 0.04^{\mathrm{bb} c c c}$ & 0.02 & $3.28 \pm 0.2$ \\
\hline $1 / 100$ & $1.39 \pm 0.25^{\mathrm{a}}$ & 0.01 & $1.89 \pm 0.03^{\text {aaa } b b c c c}$ & 0.02 & $1.8 \pm 0.03$ \\
\hline $1 / 1000$ & $0.65 \pm 0.02$ & 0.015 & $1.02 \pm 0.04^{\text {aaa } b b c c c}$ & 0.03 & $1 \pm 0.28$ \\
\hline
\end{tabular}

$\log _{10}$ of genomic copies are reported as mean \pm standard deviation. $a$ or $b p<0.5 ; 2 a$ or $2 b p<0.01 ; 3 a$ $\mathrm{p}<0.001$.

(a) for diluted samples compared with pure; (b) for LDPE compared with PVDF; (c) for sea water comparted with membrane

This article is protected by copyright. All rights reserved. 